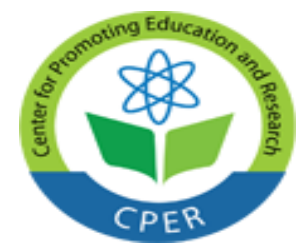

VOL: 1, ISSUE: 10

October/2019

https://ijssppnet.com/

E-ISSN: 2663-7200

DOI: 10.33642/ijsspp.v1n10p1

CCenter for Promoting Education and Research (CPER) USA

WWW.cpernet.org

\title{
EFFECT OF WORK ENVIRONMENT AND COMPETENCE TO PERFORMANCE ORGANIZATION THROUGH JOB SATISFACTION PT. UBIN KERAMIK KEMENANGAN
}

Deki Krisna Aditya

Universitas Krisnadwipayana

Po Box 7774 / Jat Cm Jakarta, Indonesia

Email: dekikrisna@gmail.com

Indonesia

Suharto

Universitas Krisnadwipayana

Po Box 7774 / Jat Cm Jakarta, Indonesia

Email: suharto@unkris.ac.id

Indonesia

P. Eddy Sanusi Silitonga

Universitas Krisnadwipayana

Po Box 7774 / Jat Cm Jakarta, Indonesia

Email: eddysanusi@unkris.ac.id

Indonesia

\section{ABSTRACT}

This study aimed to determine the effect of the work environment and competence to organizational performance simultaneously, determine the effect of the work environment on the performance of an organization partially, the effect of competence to organizational performance partially, determine the effect of job satisfaction on organizational performance partially, determine the effect of the working environment to organizational performance through job satisfaction and the effect of competence to organizational performance through job satisfaction. The study was conducted at PT. Ubin Keramik Kemenangan. Sampling using saturated samples involving 161 employees in all parts of the organization. Analysis of data using path analysis.

Based on data analysis known that the working environment and competence variables affect the performance of the organization simultaneously. Work environment variables affect the performance of an organization partially. Competence variables affect the performance of an organization partially. Competence variables affect the performance of an organization partially. Job satisfaction can provide an improved impact between the work environment and competence to organizational performance.

\section{Key words: work environment, competence, job satisfaction, organizational performance}

\section{Introduction}

Every company needs a good performance in the organization. Organizational performance must be achieved so that companies in developing and still be recognized by companies and consumers in the future. The performance of the organization is generated by an organization that includes the results of that financial performance such as profit, as measured by return on assets, return on investment and so on, the performance of products such as the expansion of market share, and sales. Besides the return of shareholders, a return of shareholders and increase the economy of shareholders.

The organization's performance is influenced by the working environment, competence and job satisfaction. The working environment is both internal and external conditions that can affect morale and thus can be expected to 


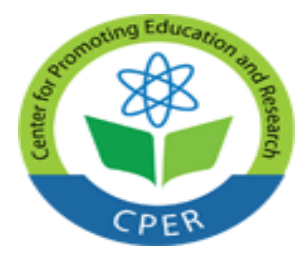

VOL: 1, ISSUE: 10

October/2019

https://ijssppnet.com/

E-ISSN: 2663-7200

DOI: 10.33642/ijsspp.v1n10p1

\section{(C) Center for Promoting Education and Research (CPER) USA}

WWW.cpernet.org

finish the job faster and better. According to Sedarmayanti (2013:12) is said to be a good working environment or as if a human can undertake optimal, healthy, safe, and comfortable. Suitability of the working environment can be seen as a result of a longer period further work environments are less well able to sue labor and more time and do not support obtaining an efficient work system design.

In some areas of the organization's performance can also be measured by other things such as strategic planning, operations, finance, legal and organizational development. In developing the institution or organization is a necessity to survive in the competitive world climate.

Competence is characteristic of the person relating to effective performance and or excel in a particular work situation. Competence is said to be the basic characteristics for the individual characteristics are part of deep and attached to the personality of a person that can be used to predict a variety of specific work situation. Then it was said on the association between the behavior and performance due to competence cause or can predict the behavior and performance. Competence is the nature of being owned or part-depth personality and inherent to the person and behavior that can be predicted in a variety of circumstances and the job duties as an encouragement for achievement and a desire to have tried to carry out tasks effectively. Discrepancies in competencies are what distinguishes superior perpetrators of actors who excel limited. Limited competence and special competence for a particular job is a pattern or guidance in the selection of employees, planning the transfer of tasks, assessment and development work.

Job satisfaction also has an impact on organizational performance. Job satisfaction is one of the psychological aspects that reflect one's feelings toward his work, he will be satisfied with the fit between the capabilities, skills, and expectations with the job he faced. Satisfaction is a subjective condition that is the result of conclusions based on a comparison of what is received by employees from their jobs compared with the expected, desired, and thinking as being inappropriate or entitled to it. Job satisfaction is an expression of one's feelings about welfare for doing that job satisfaction is a person's attitude towards work. That attitude comes from their perception of the work, that perception is a cognitive process that is used by a person to interpret and understand the perspectives of individuals in seeing the same thing differently. Job satisfaction also is a result of the employees' perception of how well the work and give the items considered important.

\section{Literature Review}

\section{Work Environment}

According to Nitisemito (2000:159), the working environment is both internal and external conditions that can affect morale and thus can be expected to finish the job faster and better. According to Sedarmayanti (2013:12) is said to be a good working environment or as if a human can undertake optimal, healthy, safe, and comfortable. Suitability of the working environment can be seen as a result of a longer period further work environments are less well able to sue labor and more time and do not support obtaining an efficient work system design.

Type of work environment is divided into two, namely: (a) Environmental physical labor is a state of physical objects that are around the workplace that may affect personal either directly or indirectly (b) Work environment Non-physical is all the circumstances occur with regard to the employment relationship, good relations with superiors and with the relationships among co-workers, or subordinates.

\section{Competence}

Competence according to Spencer and Spencer (1993) is the basic characteristics that are owned by an individual related causally to meet the criteria necessary to occupy a position. Competence consists of five types of characteristics, namely the motive (consistent willingness as well as a cause of action), congenital (character and consistent response), the concept of self (self-image), knowledge (information in a particular field) and skills (the ability to carry out tasks). 


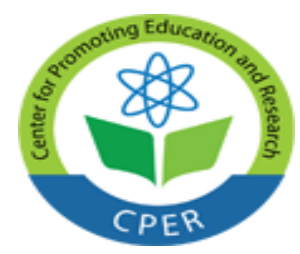

VOL: 1, ISSUE: 10

October/2019

https://ijssppnet.com/

E-ISSN: 2663-7200

DOI: 10.33642/ijsspp.v1n10p1

\section{(C) Center for Promoting Education and Research (CPER) USA}

WWW.cpernet.org

This is in line with the opinion and Becker (2005:24) that the competency refers to an individual's knowledge, skills, abilities or personality characteristics that directly influence job performance. That is, competence contains aspects of knowledge, skills and the ability or personality characteristics that affect performance.

Competence comes from the word "competency" is a noun which, according to Powell (1997:142) is defined as 1) the skills, ability, competence 2) authority. The adjective of competence is competent which means competent, capable, and agile. The statement means is competence is equal to the sense of competence according to Robbins (2013:38) that competence is the "ability or a person's capacity to perform various tasks in a job, where this capability is determined by two (2) factors which intellectual ability and physical ability.

Definition of competence as a skill or ability is also proposed by Roe (2001:73) as follows: Competence is defined as the ability to adequately perform a task, duty or role. Competence integrates knowledge, skills, personal values, and attitudes. Competence builds on knowledge and skills and is acquired through work experience and learning by doing "Competence can be described as the ability to carry out the tasks, roles or tasks, the ability to integrate knowledge, skills, attitudes and personal values, and the ability to build knowledge and skills based on experience and lessons.

Competence is characteristic of the person relating to effective performance and or excel in a particular work situation. Competence is said to be the basic characteristics for the individual characteristics are part of deep and attached to the personality of a person that can be used to predict a variety of specific work situation. Then it was said on the association between the behavior and performance due to competence cause or can predict behavior and performance.

\section{Job Satisfaction}

Job satisfaction according to Martoyo (1992:115), essentially a psychological one aspect that reflects one's feelings toward his work, he will be satisfied with the fit between the capabilities, skills, and expectations with the job he faced. Satisfaction is a subjective condition that is the result of conclusions based on a comparison of what is received by employees from their jobs compared with the expected, desired, and thinking as being inappropriate or entitled to it. While every employee subjectively determines how the work was satisfactory.

By As'ad (2004:104) job satisfaction is closely related to the attitude of employees toward his work, the work situation, cooperation between leaders and employees. Meanwhile, according to Blum (1986) in As'ad (2004:104) suggests that job satisfaction is the general attitude that is the result of some special attitude towards factors factors work, adjustment and individual social relationships outside of work.

Of limits on job satisfaction, we can conclude simply that job satisfaction is one's feelings toward his work. This means that the concept of job satisfaction to see it as the result of human interaction to their work environment. The higher the perceived assessment of the activities following the desire of individuals, the higher the satisfaction with the activity. So, the outline of job satisfaction can be defined as a pleasant or unpleasant in which employees view his work.

\section{Organizational Performance}

According to Richard et al (2010), the performance of the organization is generated by organizations that include results (outcomes) that the financial performance such as profit, as measured by return on assets, return on investment and so on, the performance of the market such as the expansion of market share and sales. Besides the return of shareholders, a return of shareholders and increase the economy of shareholders. In some areas of the organization's performance can also be measured by other things such as strategic planning, operations, finance, legal 


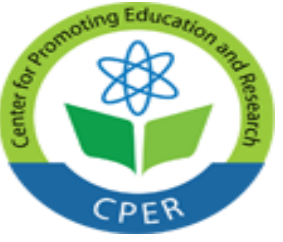

VOL: 1, ISSUE: 10

October/2019

https://ijssppnet.com/

E-ISSN: 2663-7200

DOI: 10.33642/ijsspp.v1n10p1

\section{CCenter for Promoting Education and Research (CPER) USA}

WwW.cpernet.org

and organizational development. In developing the institution or organization is a necessity to survive in the competitive world climate.

The purpose of productivity associated with the development of that organization (Shrestha,1997). Small organizations that have a desire to continue to grow and become large. The growing organization to accommodate development itself.

\section{Research Methods}

\section{Research Design}

This research uses an explanatory analysis approach. This means that each of the variables presented in the hypothesis will be observed by testing the causal relationship of independent variables on the dependent variable. Relationships between variables can be described in terms of the path analysis diagram as follows:

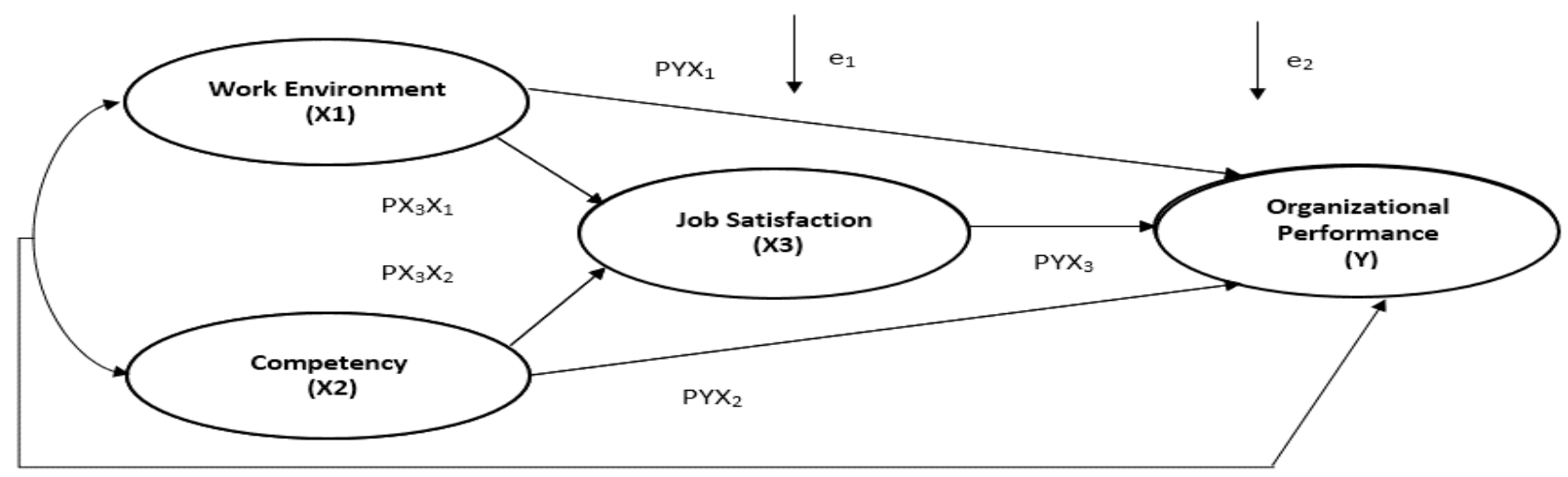

Figure 1. Framework Research Model

\section{Object of Research}

The study was conducted in PT. Ubin Keramik Kemenangan. The company is located in Cullinan, Bogor and producing ceramics with various types.

\section{Population and Sample Research}

The population is a generalization region consisting of the objects that have a certain quantity and characteristics defined by the researchers to learn and then drawn conclusions (Sugiyono,2014). Samples were towing the majority of the population to represent the entire population (Surakhmad,2001). Samples used all employees as many as 161 people in the area of the organization.

\section{ResultInfluence on Work Environment and Competence on Organizational Performance}

Based on the results of data analysis structural equation $\mathrm{Y}=0.458 \mathrm{X} 1+0.562 \mathrm{X} 2$

Calculated $F$ value of 119.167 and significance of 0.00 . This value is less than 0.05 . This means that the work environment and competence variables affect the performance of the organization simultaneously. The magnitude of the effect of the independent variable on the dependent variable can be seen from the $r$ squared value of 0.601 means that the working environment and competence variables affect the performance of the organization by $60.1 \%$ while the rest influenced by other variables that are not incorporated into the model equations.

\section{Influence of Work Environment on Organizational Performance}

Based on the results of data analysis structural equation $\mathrm{Y}=0.541 \mathrm{X} 1$ 


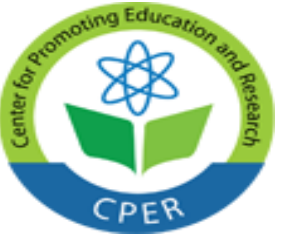

VOL: 1, ISSUE: 10

October/2019

https://ijssppnet.com/

E-ISSN: 2663-7200

DOI: 10.33642/ijsspp.v1n10p1

\section{(C) Center for Promoting Education and Research (CPER) USA}

WWW.cpernet.org

The results of data analysis known that the coefficient of 0.541 for the working environment. $\mathrm{T}$ value of 8.113. The significant value of 0.00 . The significance value smaller than 0.05 . This means that the work environment variables affect the performance of an organization partially. $R$ squared value of 0.293 . This means that the work environment variables influence the performance of $29.3 \%$ and the rest influenced by other variables not included in the model equations.

\section{Influence Analysis of Competence on Organizational Performance}

Based on the results of data analysis structural equation $\mathrm{Y}=0.630 \mathrm{X} 2$

The results of data analysis known that the coefficient of 0.630 competence. $T$ value of 10.222. The significant value of 0.00 . The significance value smaller than 0.05 . This means that the competence variables affect the performance of an organization partially. The amount of influence competence on the performance of organizational can be seen $\mathrm{R}$ squared value of 0.397 . This means that the effect of variable competence on organizational performance amounted to $39.7 \%$ and the rest influenced by other variables not included in the model equations.

\section{Analysis of Effect of Job Satisfaction on Organizational Performance}

Based on the results of data analysis structural equation $\mathrm{Y}=0.856 \mathrm{X} 3$

Based on the results of data analysis known that job satisfaction coefficient of 0.856 . T value of 20.890. The significant value of 0.00 . The significance value smaller than 0.05 . This means that job satisfaction variables affect the performance of an organization partially. $\mathrm{R}$ squared value of 0.733 . This means the effect of job satisfaction variables on organizational performance and the remaining $73.3 \%$ is influenced by other variables that are not incorporated into the model equations.

\section{Influence Analysis of Work Environment on Organizational Performance Through Job Satisfaction}

Based on the partial path analysis above, it can be described as follows. The analysis is an analysis in line with the structure of this sub-image.

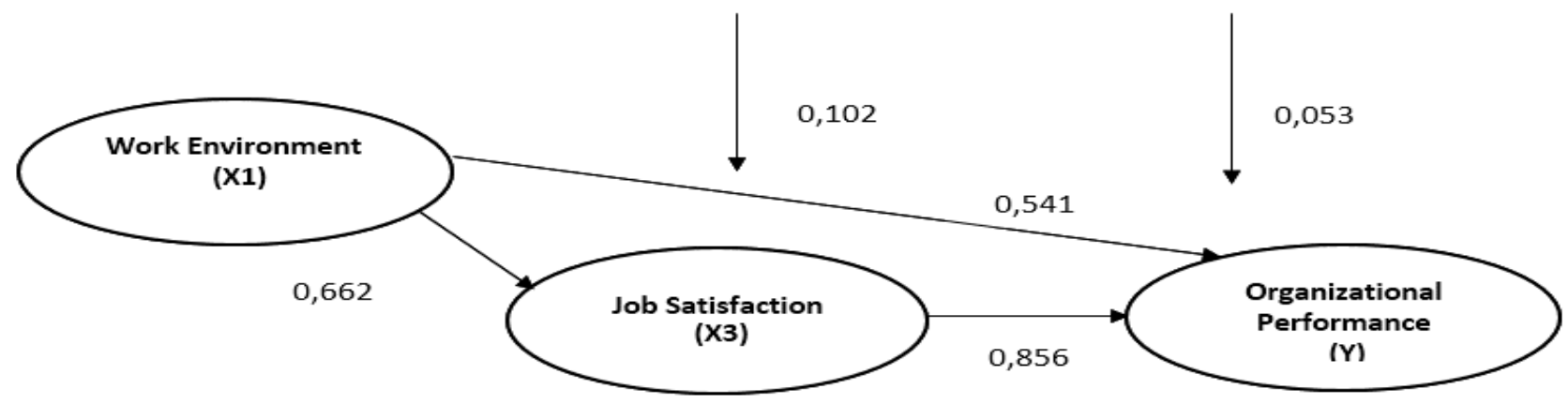

Figure 2. Path Analysis of X1 to Y through X3

Based on the picture above can be seen that the influence of the working environment on the performance of the organization is 0.541 . The influence of the working environment on organizational performance through job satisfaction is $0.662 \times 0.856=0.567$. In this case, the indirect effect is greater than the direct effect so that it can be said that job satisfaction variables as an intervening variable.

\section{Analysis of Effect on Competence on Organizational Performance Through Job Satisfaction}

Based on the partial path analysis above, it can be described as follows. The analysis is an analysis in line with the structure of this sub-image. 


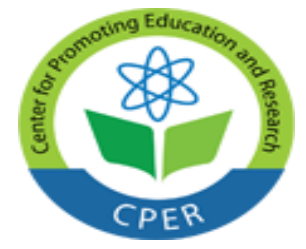

VOL: 1, ISSUE: 10

October/2019

https://ijssppnet.com/

E-ISSN: 2663-7200

DOI: 10.33642/ijsspp.v1n10p1

\section{(C) Center for Promoting Education and Research (CPER) USA}

WWW.cpernet.org

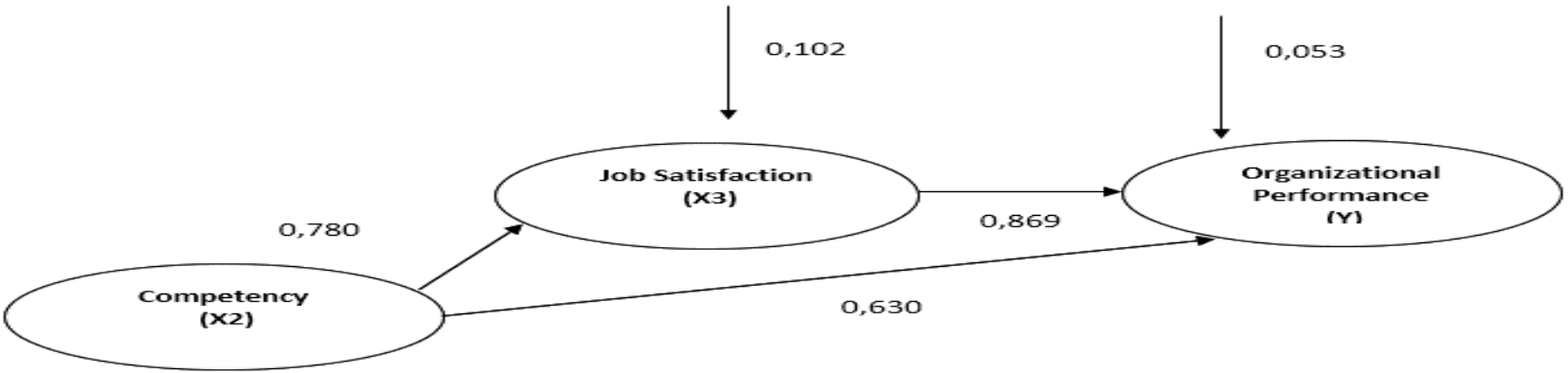

Figure 3. Analysis of Influence X2 to Y Through X3

Based on the picture above it can be seen that the direct effect of competence to organizational performance is 0.630. While the effect of competence to organizational performance through job satisfaction is $0.780 \times 0.856=$ 0.668. In this case smaller than the direct influence indirect influence so that it can be said that the variables of job satisfaction as an intervening variable.

\section{Conclusions and Suggestions}

\section{Conclusion}

Work environment and competence variables affect the performance of the organization simultaneously. $\mathrm{F}$ value calculated at 119.167 and the significance of 0.00 . This value is less than 0.05 . $\mathrm{R}$ squared value of $60.1 \%$ means that the working environment and competence variables affect the performance of the organization by $60.1 \%$ while the rest influenced by other variables that are not incorporated into the model equations.

Work environment variables affect the performance of an organization partially. $\mathrm{T}$ value of 8.113. The significant value of 0.00 . The significance value smaller than 0.05 . R squared value of 0.293 . This means that the work environment variables influence the performance of $29.3 \%$ and the rest influenced by other variables not included in the model equations.

Competence variables affect the performance of an organization partially. T value of 10.222 . The significant value of 0.00 . The significance value smaller than 0.05 . R squared value of 0.397 . This means that the effect of variable competence on organizational performance amounted to $39.7 \%$ and the rest influenced by other variables not included in the model equations.

Job satisfaction variables affect the performance of an organization partially. $\mathrm{T}$ value of 20.890. The significant value of 0.00 . The significance value smaller than 0.05 . R squared value of 0.733 . This means the effect of job satisfaction variables on organizational performance and the remaining $73.3 \%$ is influenced by other variables that are not incorporated into the model equations.

The influence of the working environment on the performance of the organization is 0.541 . The influence of the working environment on performance through job satisfaction is $0.662 \times 0.856=0.567$. In this case, the indirect effect is greater than the direct effect so that it can be said that the variables of job satisfaction as an intervening variable.

The direct effect of competence on organizational performance is .630 . While the effect of competence to organizational performance through job satisfaction is $0.780 x 0.856=0.668$. In this case smaller than the direct influence indirect influence so that it can be said that job satisfaction variables work as an intervening variable.

\section{Suggestion}

The working environment is both internal and external conditions that can affect morale and thus can be expected to 


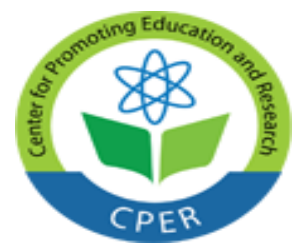

VOL: 1, ISSUE: 10

October/2019

https://ijssppnet.com/

E-ISSN: 2663-7200

DOI: 10.33642/ijsspp.v1n10p1

CCenter for Promoting Education and Research (CPER) USA

WwW.cpernet.org

finish the job faster and better (Nitisemito,1992). The working environment can be improved by improving working conditions, labor relations and the availability of facilities at work.

Competence according to Spencer and Spencer (1993) is the basic characteristics that are owned by an individual related causally to meet the criteria necessary to occupy a position. Competence can be improved by increasing the consistency of the employees of the motive, improve character factors, develop a picture of themselves, develop their knowledge and skills.

Job satisfaction is an assessment, a feeling or attitude of a person or employee to work and relate to the working environment and so on. Job satisfaction can be improved by increasing salaries, improving the ability to complete the job itself, promotion, supervision, and co-workers.

\section{References}

Alex S. Nitisemito. (2000). Manajemen Personalia: Manajemen Sumber Daya Manusia, Ed. 3. Ghalia Indonesia, Jakarta.

As’ad, Moh, (2004). Psikologi Industri: Seri ilmu Sumber Daya Manusia, Penerbit Liberty, Yogyakarta.

Becker, Brian E., Huselid, Mark A., \& Ulrich, Dave. (2009). The HR Scorecard: Mengaitkan Manusia, Strategi, dan Kinerja. Jakarta: Erlangga.

Daft, Richard L. (2010). Manajemen Edisi Kelima Jilid Satu. Jakarta: Erlangga.

Powell, J., (1997). Improving Child Health, Geneva, World Health Organization.

Robbins, Stephen P \& Judge, Timothy A. (2013). Organizational Behavior Edition 15. New Jersey: Pearson Education

Roe, Robert A. (2001). Trust Implications for Performance and Effectiveness. European Journal Vol. 12, No. 5.

Sedarmayanti. (2013). Manajemen Sumber Daya Manusia, Reformasi Birokrasi Manajemen Pegawai Negeri Sipil. Rafika Aditama, Bandung.

Shrestha, Taliziduhu, (1997). Metodologi Ilmu Pemerintahan. Jakarta: Rineka Cipta.

Spencer, Lyle M. And Signe M. Spencer. (1993). Competence Work: Model for Superior Performance. John Wiley and Sons, Inc.

Sugiyono. (2014). Metode Penelitian Kuantitatif, Kualitatif, dan Kombinasi (Mixed Methods). Bandung: Alfabeta Susilo Martoyo, (1992). Manajemen Sumber Daya Manusia. Jakarta : BPFE.

Winarno Surakhmad. (2001). Pengantar Penelitian Ilmiah Dasar Metode Teknik. Bandung: Tarsito 